\title{
The dark side of fungal competition and resource capture in wood: Zone line spalting from science to application
}

\author{
Hugh Morris $^{\mathrm{a}, \mathrm{b}, *}$, Kevin T. Smith ${ }^{\mathrm{c}}$, Seri C. Robinson ${ }^{\mathrm{d}}$, Maximilian Göttelmann ${ }^{\mathrm{e}}$, \\ Siegfried Fink ${ }^{\mathrm{e}}$, Francis W.M.R. Schwarze ${ }^{\mathrm{a}}$ \\ a Laboratory for Cellulose E Wood Materials, Empa-Swiss Federal Laboratories for Materials Science and Technology, Lerchenfeldstrasse 5, CH-9014 St. Gallen, Switzerland \\ b Institute of Botany, BOKU Vienna, Vienna, Austria \\ c United States Department of Agriculture Forest Service, Northern Research Station, 271 Mast Road, Durham, NH 03824, USA \\ d Department of Wood Science and Engineering, Oregon State University, 119 Richardson, Corvallis, OR 97331, USA \\ e Chair of Forest Botany, University of Freiburg, Bertoldstr. 17, 79085 Freiburg, Germany
}

\section{H I G H L I G H T S}

- Spalted wood is a highly sought after speciality wood product in niche furniture and construction markets.

- Spalting is a term specifically designated to any pattern in wood as a result of competition between decay-fungi.

- By manipulating fungi, the operator can create unique patterns in wood called zone lines.

- Zone lines are formed of melanin, the same pigment humans produce in their skin.

- We review a method to standardise the treatment of wood using specific fungi and how we can upscale the process.

\section{A R T I C L E I N F O}

\section{Article history:}

Received 28 November 2020

Received in revised form 6 January 2021

Accepted 11 January 2021

Available online 20 January 2021

\section{Keywords:}

Decay-fungi

Melanin

Secondary xylem

Soft rot fungi

Spalting

Zone line
GRAPHICA L A B S T R A C T

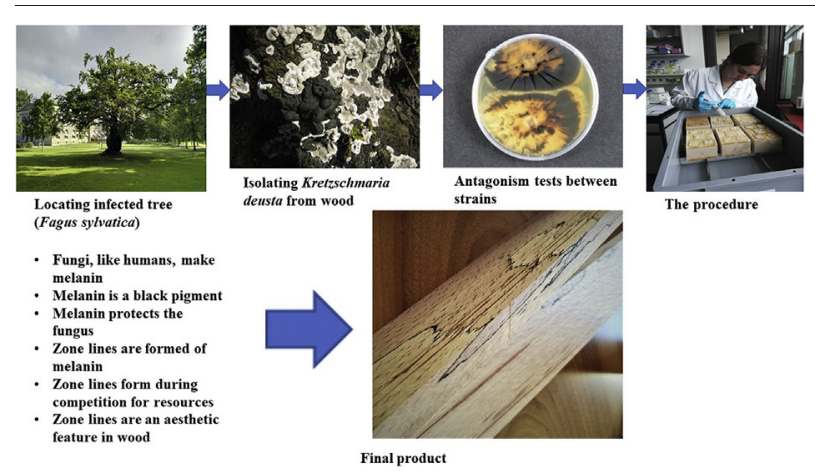

\section{A B S T R A C T}

On wood surfaces and in planar section, zones lines appear as narrow and sharply delineated dark lines within wood visibly altered ("spalted") by the decay process. In intact wood, zone lines define an irregular volume of decaying wood. They are primarily aggregations of melanised hyphae that enclose wood being decayed by a single genetic individual of a wood decay fungus. In the industry for speciality wood products, zone lines are highly valued, especially for decorative pieces produced from wood turnery. While zone lines are commonly found in naturally infected wood, they can also be induced under controlled conditions. Although with great economic potential for application, there is currently no spalting process to produce zone lines on a commercial scale for niche furniture and construction markets. Successfully spalting wood in a defined timeframe that meets industry expectations requires a knowledge of fungal species, wood colonisation strategies, fungal decay processes along with wood behaviour (i.e. its hygroscopicity), anatomy and wood mechanical properties in relation to fungal decay. This review identifies current limitations of zone-line spalting and looks at a novel approach to inducing wood by combining genetic individuals from the same fungal species, enabling the operator to homogenise the spalting method.

(c) 2021 The Author(s). Published by Elsevier Ltd. This is an open access article under the CC BY-NC-ND license (http://creativecommons.org/licenses/by-nc-nd/4.0/).

\footnotetext{
* Corresponding author at: Institute of Botany, BOKU Vienna, Vienna, Austria.

E-mail addresses: hugh.morris@boku.ac.at (H. Morris), kevin.smith3@usda.gov (K.T. Smith), seri.robinson@oregonstate.edu (S.C. Robinson),

maximilian.goettelmann@fobot.uni-freiburg.de (M. Göttelmann), siegfried.fink@fobot.uni-freiburg.de (S. Fink), francis.schwarze@empa.ch (F.W.M.R. Schwarze).
} 


\section{Contents}

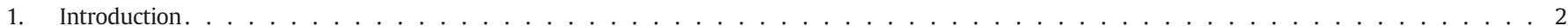

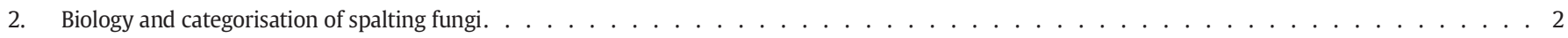

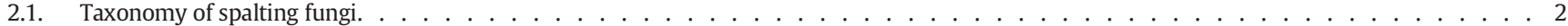

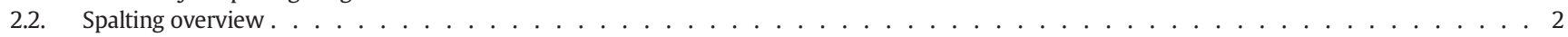

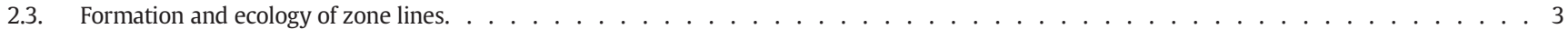

3. Zone-line formation and melanin synthesis. . . . . . . . . . . . . . . . . . . . . . . . . . . . . . . . . 5

3.1. Zone-line formation and resource capture in wood . . . . . . . . . . . . . . . . . . . . . . . . . 5

3.2. 3-dimensional zone lines versus melanised discoloration . . . . . . . . . . . . . . . . . . . . . . . . . . . . . . . . . 5

3.3. Zone-line spatial arrangement . . . . . . . . . . . . . . . . . . . . . . . . . . . . . . . 5

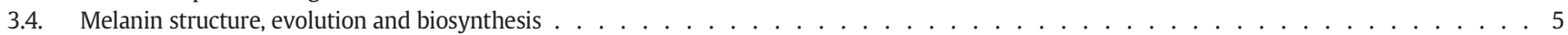

4. Current zone-line spalting methods . . . . . . . . . . . . . . . . . . . . . . . . . . . . 8

5. Standardising the spalting method for commercial-scale applications . . . . . . . . . . . . . . . . . . . . . . . . . . . . . . . . . . 8

5.1. Zone lines, wood mechanical properties, pH and wood moisture content . . . . . . . . . . . . . . . . . . . . . . . . . . 8

5.2. Decay fungi and mechanical properties . . . . . . . . . . . . . . . . . . . . . . . . . . . . . 8

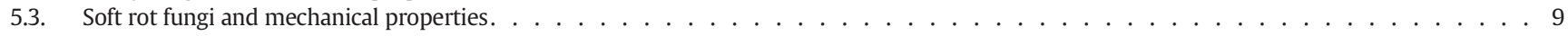

5.4. Kretzschmaria deusta and zone-line formation . . . . . . . . . . . . . . . . . . . . . . . . . . . . . . . 9

5.5. Incipient versus advanced decay and mechanical properties . . . . . . . . . . . . . . . . . . . . . . . . . . . . . . . . . . . . . . . .

5.6. Effects of $\mathrm{pH}$ and temperature on zone-line formation and decay-fungi . . . . . . . . . . . . . . . . . . . . . . . . 11

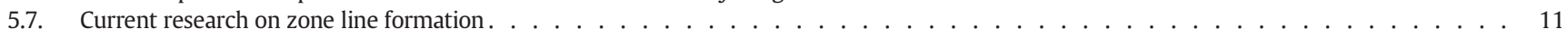

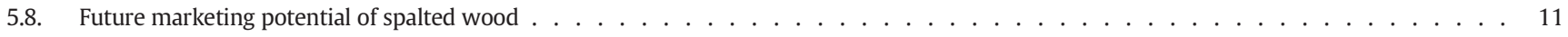

6. Discussion and future outlook . . . . . . . . . . . . . . . . . . . . . . . . . . . . . . . . . . . . . . .

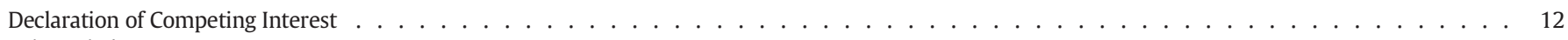

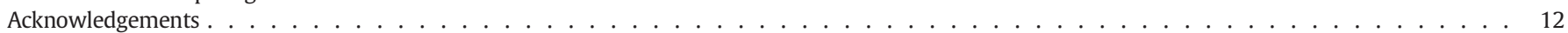

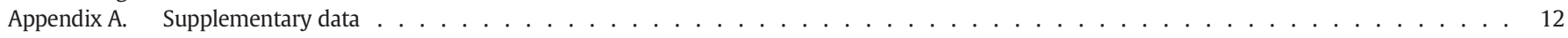

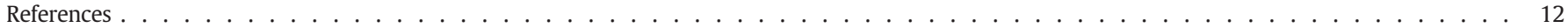

\section{Introduction}

The biotechnological prospects for wood decay fungi are numerous and diverse with potential to deliver huge economic dividends, especially in the green sector where fungi can make a significant contribution to the circular economy and climate mitigation ([2]; Meyer et al. [9,40]). Wood decomposing fungi also harbour huge potential for novel applications, such as in the development of fungal-induced bow instruments (i.e. the 'biotech Stradivarius'; [65]) and wood products with artistic appeal. Visible indicators of wood decay such as zone lines (also known as demarcation lines) and wood discoloration induced by fungi are collectively referred to as spalting or spalted wood [58]. From the timber commodity perspective, spalting is a defect and a source of lost economic value. However, for specialty craft and artisanal products, spalting has aesthetic appeal and can greatly increase the economic value of wood for artistic expression. For the forest product industry, the ability to reliably induce zone-line formation would provide a means to enhance the economic value of otherwise low-value timber products.

An understanding of wood anatomy and wood decay strategies is key to artificially produce zone-line spalting, with a history now spanning a half-century of practice. The German forest pathologist Robert Hartig [23] first described zone lines as sharply defined black lines that accompanied decay of Larix decidua wood by Armillaria mellea. In microscopic view, Hartig described zone lines as bladder-like hyphae within 3-4 rows of tracheids, resembling tyloses (Fig. 1; [23]). Later research by Campbell [10-12] concluded that zone lines were the result of competition between decay-fungi. Melvin Lindquist, a pioneer of the American woodturning craft, made zone-lined wood into an art form in the 1960s, thus establishing the spalting industry [36,58]. Mark Lindquist (son of Melvin) was a pioneer of producing zone lines in wood through burial of unspalted wood with wood shavings previously infected with fungi (e.g. Armillaria and Xylaria spp.) capable of producing zone lines [58]. In the late 1970s, students of Mark Lindquist attempted but failed to induce spalting under laboratory conditions
(Robinson, 2016). Recent advances have improved laboratory procedures to screen for suitable fungal and wood species, to manipulate moisture content and mass loss, and for digital colour analysis of zone lines $[20,57,59,75]$. However, the majority of recent advances in inducing spalting have focused on pigmentation and direct application of fungal stains to wood $[48,54,61]$ with less emphasis on zone-line production. A reliable, time-efficient method to produce zone lines is necessary to meet the potential demands for decorative furniture, flooring and millwork.

In this review, we focus on the biology and biochemistry of zone-line production and cultural methods to reliably induce spalting to meet the demands for specialty wood stock for high-value products.

\section{Biology and categorisation of spalting fungi}

\subsection{Taxonomy of spalting fungi}

The fungi associated with spalting can be categorised by fungal taxonomy, colonisation strategy, and the biochemistry of the decay process. Within mycological systematics [31], the fungi responsible for wood decay are all members of the Basidiomycota (class Agaricomycetes including members of the Hymenochaetaceae, Fomitopsidaceae, Polyporaceae) and Ascomycota (produces a soft rot decay and from family Xylariaceae, primarily). To understand zoneline formation and to choose suitable fungi to maximise potential for zone-line spalting, knowledge of the biological differences between the taxonomic groups is important (See Fig. 2 and Table 1 for definition of terms and table Supplementary Information Table 1 for fungi known to form zone lines).

\subsection{Spalting overview}

Zone-line formation is one of three types of spalting, which also include both formation and removal of pigment (fungal staining and 


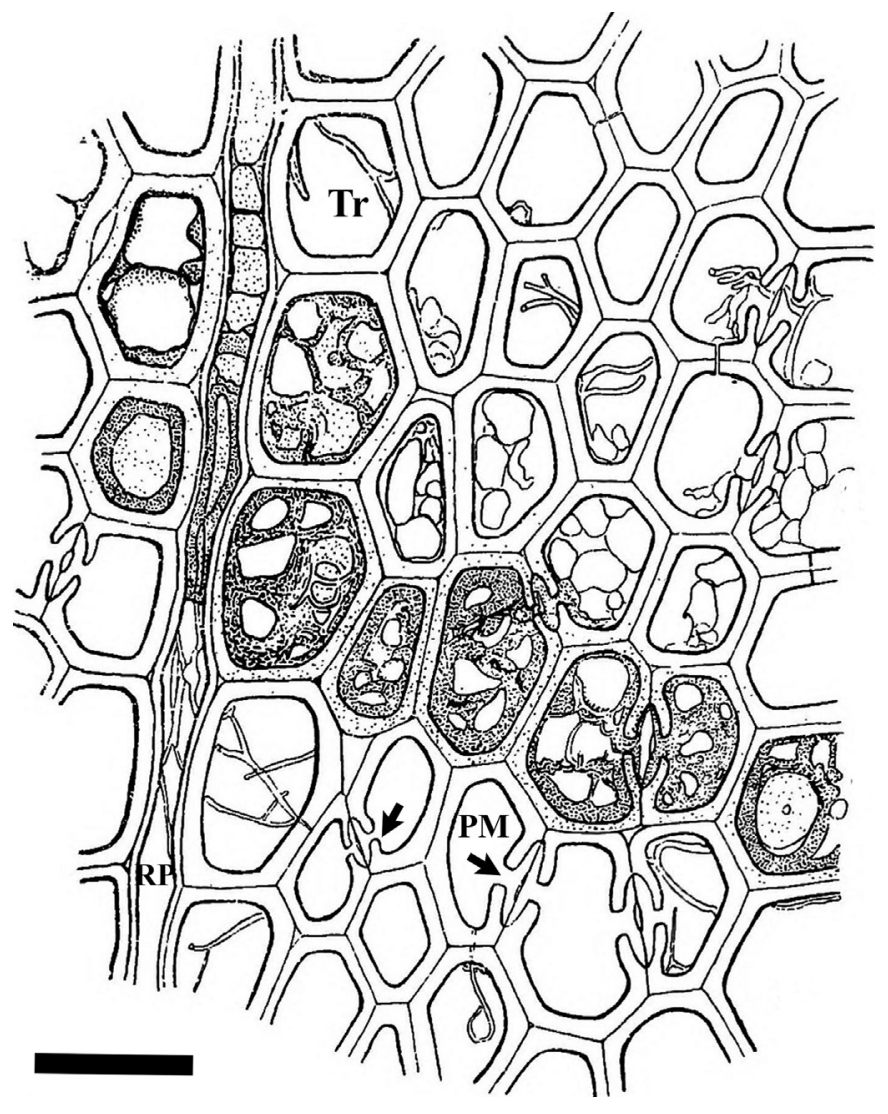

Fig. 1. An original illustration by the German forest pathologist R. Hartig [23] showing a transverse section of larch wood (Larix decidua) with a single black zone line induced by the basidiomycete Armillaria mellea. The zone line is up to four wood cells wide, where tracheid-to-tracheid torus-margo pit membranes reveal entrance points for fungal hyphae prior to melanin synthesis and accumulation. RP, ray parenchyma; Tr,tracheid; PM, pit membrane. Scale bar $=50 \mu \mathrm{m}$. Copyright permission obtained from Alamy Ltd. (https://www.alamy.com/terms/uk.aspx).

bleaching, respectively) (Table 1). Fungal staining of wood normally causes economic loss for timber products (e.g. lumber and wood pulp). The most familiar type of product stain is caused by "blue stain fungi", a polyphyletic assemblage of perithecial ascomycetes (primarily genus Ceratocystis, in a broad sense) (Kirk 2008). The blue stain fungi do not decay wood but do consume nutrients including nonstructural carbohydrates (i.e. starch and simple sugars) contained in sapwood of both conifers and angiosperm trees and in freshly-cut logs and lumber. The blue stain colour is from melanin, a group of water-insoluble pigments that are brown to black in colour and biosynthesised from the amino acid tyrosine. Melanin confers protection from UV exposure as well as environmental extremes in $\mathrm{pH}$, temperature, salinity and radioactivity $[15,71]$. In blue stain, the melanin is bound to hyphal cell walls, making the infected wood in reflected light to appear blue to grey in colour. Alternatively, extracellular secretions from the brown rot fungus Fistulina hepatica are apparently responsible for the desirable "brown oak" pigmentation in heartwood of English oak, which commands a high price in the market (Fig. 4F; [13,22]). Although there is general consensus that hyphae of $F$. hepatica deposits a 'brown material' into parenchyma, other factors may also contribute to the prized staining, such as the release of phenols (e.g. tannins, etc.) during the decay process. Other soft rot fungi responsible for blue-green spalting in wood belong to Chlorociboria (i.e. C. aerigenascens and C. aeruginosa). Chlorociboria give a range of angiosperm woods a blue-green coloration deriving from secondary metabolites (e.g. xylindein) that are released by the fungi during resource capture in wood (Fig. 2 B, D) [78].
White rot spalting appears as localized or extensive bleaching in wood, especially when confined to specific regions where the contrast with the surrounding darker wood creates a strong visual effect (Fig. 2F, G, J, K, L). Also, the bleached region is usually not a standalone spalting type and is often separated from surrounding wood by zone lines, also produced by white rot fungi (e.g. Trametes versicolor) or in many cases, soft rot fungi (Fig. 2G, L). The high contrast between white rot, wood discoloration and the surrounding darker border (zone lines) is often referred to as 'marble rot' owing to the marbled appearance [77].

Zone-line spalting is spatially defined pigmentation by melanin and other secondary metabolites (e.g. metabolites responsible for orange-red zone lines of some woods, Fig. 2C, D, E). Zone lines occur more frequently in wood of angiosperms trees than conifers due to the more frequent occurrence of white rot fungi in the former [32]. There is little to no evidence of brown rot fungi producing black melanised zone lines in wood, which may be related to the life history of this fungal group. Brown rot fungi evolved at least seven times in the Polyporales through reduction or complete loss of class II peroxidases, an efficient non-enzymatic strategy in conifers known as the Fenton reaction (Flouas et al. [18]; [32]). White rot fungi use laccase and other enzymes (including peroxidases) to synthesize melanin from catechol, which are absent in brown rot fungi [49]. The loss or reduction of class II peroxidases and laccase in brown rot fungi likely resulted in the inhibition of melanin, although this needs to be experimentally tested on a range of brown rot fungi to show that zone lines do not occur or extremely rarely as shown in Fomitopsis betulina. Strains of the latter brown rot fungus produced only faint brown zone lines lacking the dark pigmentation associated with melanin [1]. However, this could be owing to melanin derivatives associated with reduced phenoloxidases, e.g. class II peroxidases and laccase, tyrosinase, etc., rather than their complete loss during the evolutionary transition from white rot to brown rot fungi $[34,63]$.

\subsection{Formation and ecology of zone lines}

Zone lines most frequently result from the interaction of fungal hyphae produced by different genetic individuals. In wood of living trees, zone lines occur within compartments "walled off" from the functional sapwood symplast, the interconnected network of living cells. This compartmentalisation process in response to injury and infection resists the loss of wood function and the spread of infection by wood decay fungi and other microorganisms through boundary setting (Morris et al. 2016, $[9,69])$. Compartmentalisation boundaries include both constitutive features and induced changes in wood anatomy and physiology including visible reaction zones. Reaction zones are produced as a response to injury and infection and consist of a narrow layer of sapwood parenchyma and that have undergone a physiological shift to produce waterproofing and antimicrobial secondary metabolites [42]. Successful compartmentalisation maintains function in remaining, apparently uninfected sapwood. Effective compartmentalisation results in the co-existence of potentially large and old trees with wood decay fungi. Compartmentalisation boundaries can be confused with zone lines and other spalting features (e.g. [79]; Table 1). Also, another sought after artisan wood product very similar in appearance to spalted wood is termed marblewood (i.e. Zygia racemosa: Fabaceae) on account of the high contrast between the yellow body of the heartwood and the dark streaks that run through it. While both spalted wood and marblewood command a high price in niche timber markets, the streaks in marblewood are not caused by fungi but occur naturally and the term should not be confused with 'marble rot'.

Within a zone line, the fungal hyphae are highly melanised and are viewed microscopically as aggregated masses that plug the lumina of wood cells in radial, tangential and axial directions, forming 3 -dimensional self-isolating compartments of xylem space $[10,11,68]$. 

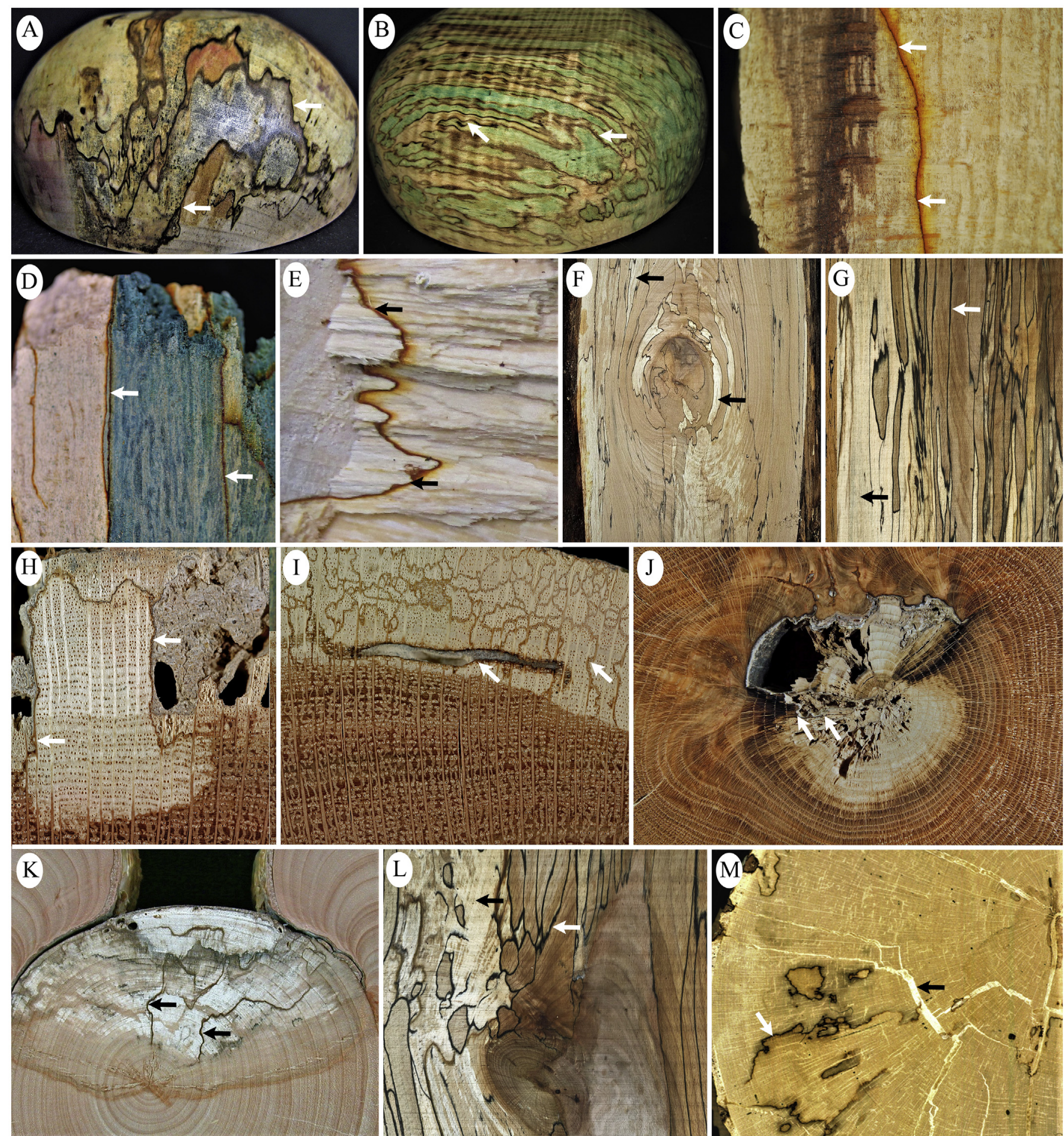

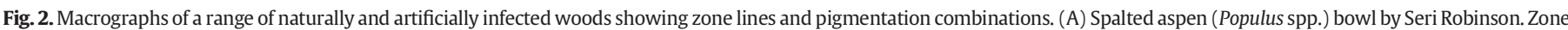

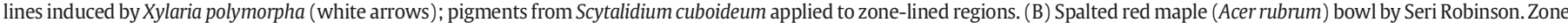

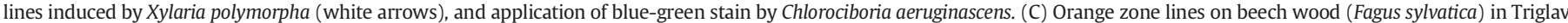

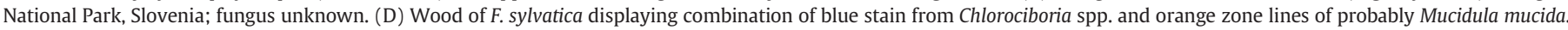

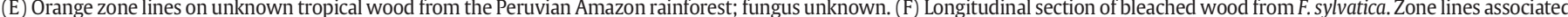

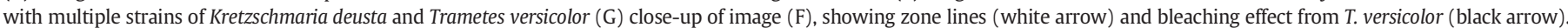

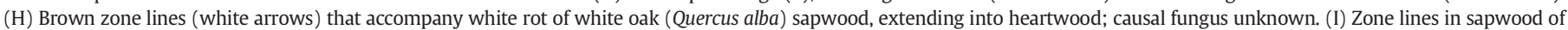

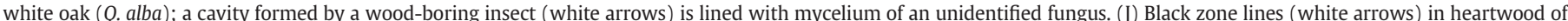

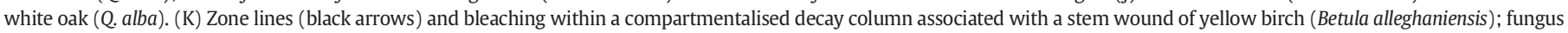
unknown. (L) Close-up of image (F). (M) Melanised surface discoloration by Fomes fomentarius (white arrow) and mycelial spread causing cracking along rays (black arrow). 
Table 1

Overview of key terms related to wood spalting.

\begin{tabular}{|c|c|}
\hline Terms & Meaning and references \\
\hline Compartmentalization & $\begin{array}{l}\text { Boundaries such as reaction and barrier zones are formed } \\
\text { through metabolism of the tree while spalting is the } \\
\text { result of activity of decay fungi and their interactions. } \\
\text { Spalting associated with wood in a living tree is } \\
\text { compartmentalised and outside of the volume of living } \\
\text { wood that contains the tree symplast. Aggressive wood } \\
\text { decay pathogens (e.g. Armillaria) may induce spalting at } \\
\text { a reaction zone or breach the compartmentalisation } \\
\text { boundary [66] }\end{array}$ \\
\hline Brown rot fungi & $\begin{array}{l}\text { Decay fungi that decompose cellulose and hemicellulose } \\
\text { of host cell walls using both non-enzymatic and } \\
\text { enzymatic processes to break down cellulose and to } \\
\text { partially modify. Rarely produce zone lines and unlikely } \\
\text { to be composed of melanin (Schwarze et al., 2007) }\end{array}$ \\
\hline Discoloration & $\begin{array}{l}\text { Melanin that forms on the surface of wood but lacks the } \\
\text { 3-dimensionality is one type of discoloration of } \\
\text { interaction zone line caused by competing fungi. Often } \\
\text { caused by aeration or surface contaminants }\end{array}$ \\
\hline Incipient decay & $\begin{array}{l}\text { An early stage of decay when fungal mycelium is } \\
\text { colonizing previously melanised host tissues prior to } \\
\text { complete attack of the cells (the typical stage). Zone lines } \\
\text { are formed during this stage in the presence of an } \\
\text { antagonist [29] }\end{array}$ \\
\hline $\begin{array}{l}\text { Inter-and-intraspecific } \\
\text { antagonism }\end{array}$ & $\begin{array}{l}\text { Interspecific antagonism is competition between species } \\
\text { while intraspecific antagonism is competition between } \\
\text { different strains of the same species resulting in zone } \\
\text { lines [6] }\end{array}$ \\
\hline Pigmentation & $\begin{array}{l}\text { A form of spalting by a range of pigments either bound } \\
\text { within hyphae (i.e. blue-stain fungi), or produced } \\
\text { extracellularly (e.g. pink-red stain from Scytalidium spp.) } \\
\text { The pigments may not directly come from the fungus, as } \\
\text { in the case of Fistulina hepatica causing brown rot of } \\
\text { Quercus robur and Castanea sativa. The brown coloration } \\
\text { may derive from a brown pigment produced by the } \\
\text { fungus or is a degradation product of tannins, cellulose } \\
\text { and hemicellulose upon decay ([22]; [13]) }\end{array}$ \\
\hline Pseudosclerotial plate & Scientific terms for zone lines \\
\hline Reaction zone & $\begin{array}{l}\text { Often confused with zone lines, but reaction zones are } \\
\text { the defensive products of living parenchyma cells in } \\
\text { plant xylem tissue [ } 42 \text { ] }\end{array}$ \\
\hline Soft rot fungi & $\begin{array}{l}\text { Hyphae of this type of decay tunnel inside lignified cell } \\
\text { walls resulting in the formation of cavities which appear } \\
\text { as minute holes in the S2 layer of transverse sections. } \\
\text { Syringl lignin is extensively degraded while guaiacyl } \\
\text { remains intact (Schwarze et al., 2007) }\end{array}$ \\
\hline White rot fungi & $\begin{array}{l}\text { Fungi in this group decay lignin hemicellulose and } \\
\text { cellulose at similar rates (simultaneous white rot) or } \\
\text { decay primarily lignin (selective delignification) at least } \\
\text { partially (Schwarze et al., 2007) }\end{array}$ \\
\hline White rot spalting & $\begin{array}{l}\text { Spalting type caused by white rot fungi that causes } \\
\text { bleaching in wood through the enzyme laccase. Can be } \\
\text { accompanied by zone lines [58] }\end{array}$ \\
\hline Zone line & $\begin{array}{l}\text { Also known as black or demarcation lines, zone lines } \\
\text { are formed of aggregated - usually melanised - hyphae } \\
\text { produced by a decay fungus usually in response to } \\
\text { another fungus apparently as a defence mechanism, or } \\
\text { to maintain appropriate water regime ([8]; Butin, } \\
\text { 1996; [68]) }\end{array}$ \\
\hline
\end{tabular}

Although usually black or dark brown, zone line colour may vary depending on the fungi and other secondary metabolites involved, with lines that vary in thickness and colour intensity [52,58].

Fungi have evolved to occupy specific niches during the wood decomposition process $[7,27]$. Zone lines are visible traces of competition ("battle traces") among fungal communities for resource acquisition, community development and subsequent self-isolation [6,27]. The dark lines are 3-dimensional markers that define spatial components of fungal population and community dynamics from which a range of species or strains of a single species can be isolated directly before being grown in culture $[25,68]$.

\section{Zone-line formation and melanin synthesis}

\subsection{Zone-line formation and resource capture in wood}

Zone lines protect fungal communities primarily through defensive self-isolation and secondarily by influencing wood moisture content and countering host tree defences. Self-isolation may be between separate species or between strains within the same species (i.e. intraspecific antagonism; [52]).

Boddy [6] termed zone lines associated with self-isolation as 'interaction zone lines' and are distinct from pseudosclerotial plates, which contribute to maintain a favourable wood moisture content. Examples of the latter are zone lines produced by K. deusta that may result in reduced wood moisture content that favours growth of the decay fungus $[8,24]$. In contrast, Armillaria may form zone lines to maintain elevated wood moisture content. Nelson [43] provides indirect evidence of this level of control in that the survival of the wood decay pathogen Coniferiporia weirii in buried wood blocks was associated with the presence of zone lines and the maintenance of favourable conditions for fungal survival. Injury to the hyphae from secondary metabolites has been suggested by Pearce [46] to elicit the formation of pseudosclerotial plates of $K$. deusta after contact with reaction zones (Fig. 3A-H).

\subsection{3-dimensional zone lines versus melanised discoloration}

In freshly inoculated processed wood such as sawn timber and boards, true 3-dimensional zone lines are unlikely without inter-orintra specific antagonism. Xylaria polymorpha has been identified as the only fungus to form zone lines 3-dimensionally without an antagonist in processed wood [55]. However, without an antagonist, the result is usually surface discoloration caused by extracellular melanin produced in response to environmental stress such as desiccation. In latter cases, the lines lack definition and depth (e.g. Fomes fomentarius on European beech; Fig. 2M). Non-interaction zone lines can form on wood surfaces when exposed to air or even metals such as copper [56]. Importantly, single fungal strains are ineffective in 3-dimensional zone-line formation, a fact to consider during industrial-scale application.

\subsection{Zone-line spatial arrangement}

Zone lines may be arranged as single or double lines (Fig. 3A-F). Single zone lines are likely to be formed by the interaction of two species of fungi for which only one of the species' produces the melanin-induced demarcation line. Alternatively, single zone lines may be produced in response to environmental stress. Double zone lines are often formed between two strains of a species, where each strain forms its own line, with the remaining space between the dark lines being a kind of "no man's land" (Fig. 3D-F). Although no living fungi are likely to exist between zone lines during the inoculation process, Chaetosphaeria myriocarpa and Rhinocladiella spp. have been confirmed as occupying the space in naturally infected trees [6,51]. The gap between the lines can vary in size and is often so close as to appear in cross-section as a single large zone line. Double zone lines offer a unique aestheticism that may add extra appeal, giving more choice to the craftsman and consumer.

\subsection{Melanin structure, evolution and biosynthesis}

Melanin, the most common pigment associated with zone-line formation, is usually produced intracellularly within zone lines but may also line the secondary walls of wood cells [76]. In hyphal cells, presence of the pigment is usually associated with reduced or absent protoplasm. Melanin is a high molecular weight polymer that varies in form and structure and is synthesised in the hyphal cell wall through two distinct pathways. Ascomycetes (e.g. Xylaria spp.) synthesize melanin through 

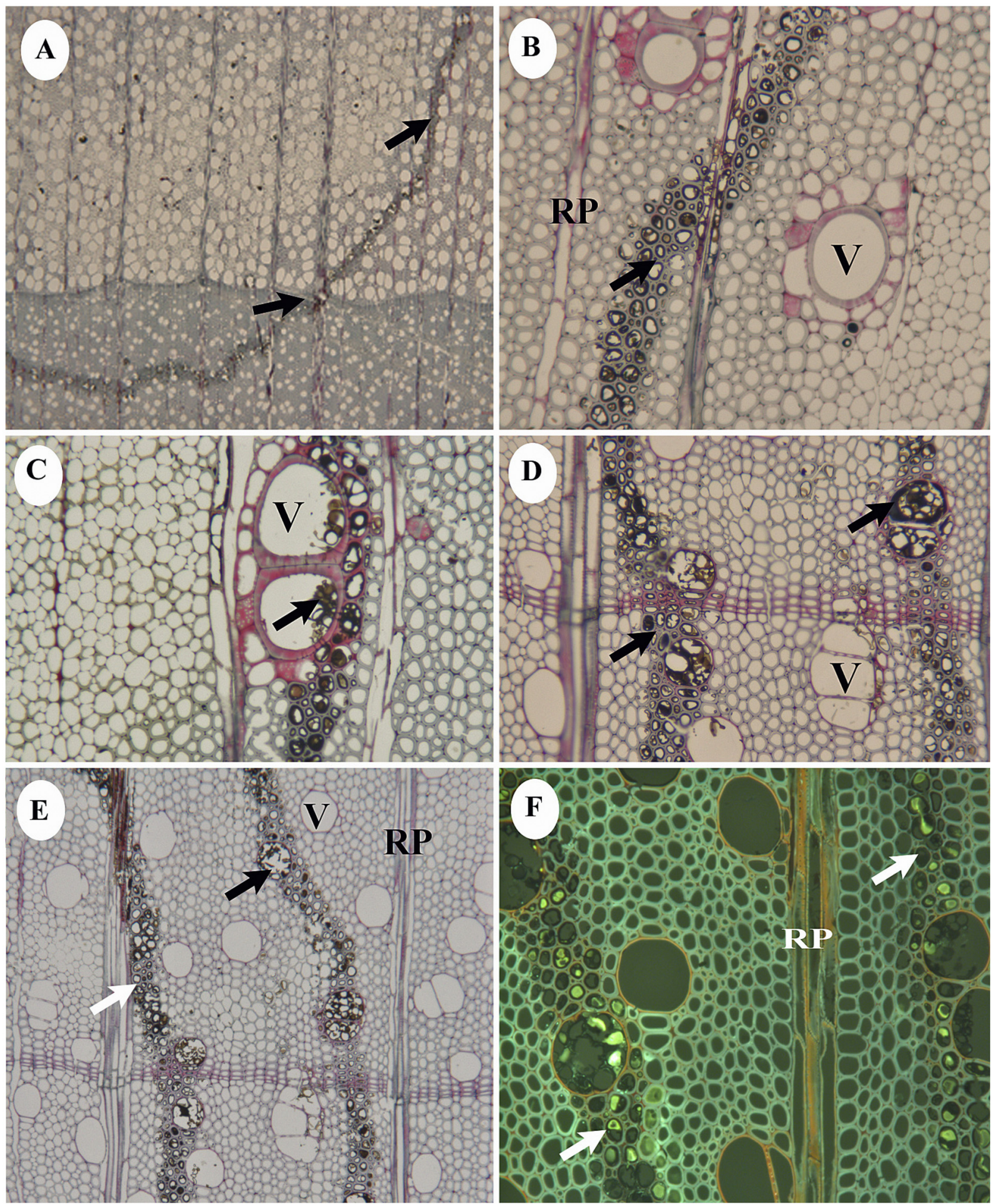

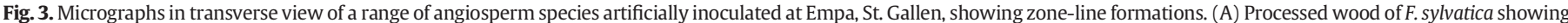
a single zone line after artificial incubation, pairing Kretzschmaria deusta with Trametes pubescens, with the 'black' line being formed by the former (black arrows). (B) Fraxinus excelsior (Oleaceae) wood incubated with K. deusta and T. pubescens where the zone line five cells wide (black arrow) runs diagonally, traversing ray parenchyma between vessels. (C) Close-up of image (B) showing the melanised zone lines circumventing and partially entering a vessel group. Hyphae can be seen emerging from pseudosclerotia (black arrow). (D) Double zone lines induced after pairing two strains of $K$. deusta in processed wood of Acer pseudoplatanus (Sapindaceae), with each strain forming a single 3-dimensional line. Aggregated pseudosclerotial masses occlude a vessel group, similar to tyloses in appearance (black arrow, right). (E) Double zone lines radially oriented through a growth ring, vessels and ray parenchyma, as image (D). (F) Fluorescent image of (E, D) with bright green fluorescence in vessels indicating phenolic composition of melanin (white arrows). 

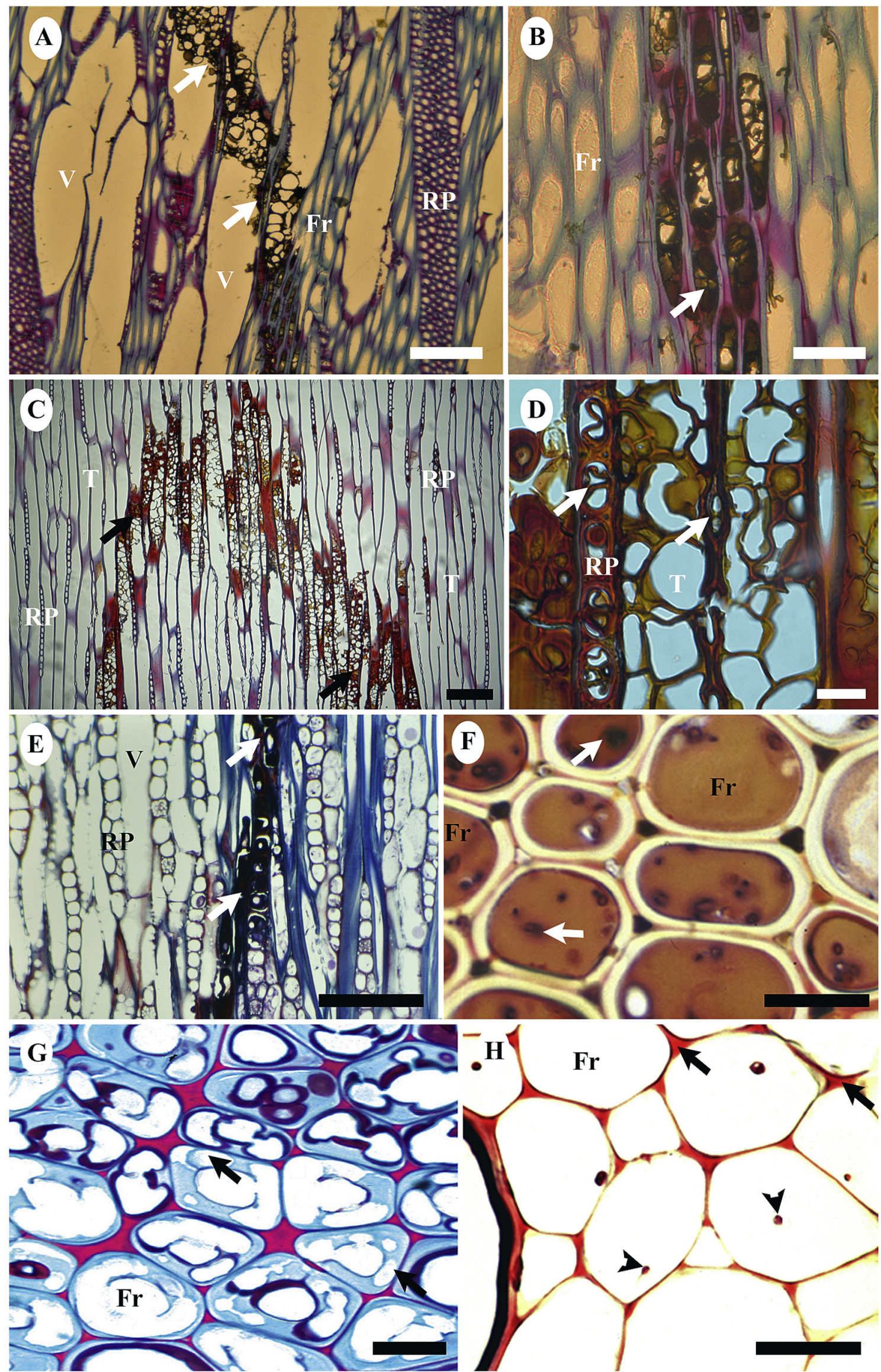
the oxidative polymerisation of the phenolic compounds catechol or 1,8-dihydroxynaphtalene (DHN), resulting in allomelanin and pyomelanin. Basidiomycetes (e.g. Armillaria spp.) form melanin through 4, 3,4-dihydroxyphenylalanine (DOPA, resulting in eumelanin) and cysteinyl-DOPA (resulting in pheomelanin) $[53,73,74]$. Extracellular secretion of melanin minimises degradation of plant cells and supports structural integrity of zone lines and fungus survivability $[4,76]$. The melanin appears to fill pit membranes and the lumina of adjoining cells where it helps form a complete and continuous almost impenetrable closely packed barrier (e.g. Armillaria ostoyae in Picea abies, Fig. 4C, D). The stability of melanin pigmentation in spalted wood exposed to indoor lighting has not been broadly established but is essential to determine indoor applications (e.g. decorative partitioning, furniture, tables, etc.). As far as we know, melanin stability has not been investigated thus far for indoor use but can be tested through a number of ways, for example with a Xenon-arc lamp fitted with a $3 \mathrm{~mm}$ window glass filter (to simulate spalted wood products indoors) or a Chroma Mater CR-200 (KONICA MINOLTA) [21].

\section{Current zone-line spalting methods}

Although there is an increasing demand for natural wood material with aesthetic character $[58,67]$, the common methods to produce zone lines are slow (many months to years) and inadequate to produce the volume to meet commerical demands, particularly for large-scale projects in the premium furniture market. There is no standard scientific method to produce wood with zone lines in large commercial large com quantities nor the basis to predict the patterns and fungal behaviour under controlled conditions. Historically, spalting has been carried out by workers from the wood craft industry with techniques based on anecdote and lacking in scientific rigour. The primary technique attempts to mimic the natural process through burial of wood stock in the forest floor and natural colonisation by extant fungi, providing unpredictable results. During natural colonisation, both interspecific and intraspecific competition between basidiomycetes and ascomycetes is at play with a diverse range of fungal species and strains of a single species. In temperate world regions, the spalting fungi that colonise dead wood piles include the white rot basidiomycetes Trametes spp., Bjerkandera adusta, Armillaria spp., and ascomycetes Kretzschmaria deusta, Daldinia concentrica and Xylaria spp., etc. ([52]; Cooke and Rayner, 1985; [8]).

More sophisticated methods to induce zone line formation have included incubation of stacked piles of wood in a warehouse with imprecise controls of temperature and wood moisture levels (moisture content of the wood at circa 30\%). The most scientific approach todate also takes 3-4 months with wood stacked in opaque plastic tubs containing $3 \mathrm{~cm}$ of water or moistened vermiculate. Spalting fungi are applied using various approaches (e.g. plugs, sprays, etc). The wood stacks are incubated in a heated space and maintained at a moisture content $<35 \%$ [58]. Different successful combinations of white rot basidiomycetes have been used to form zone lines, including the white rot fungi Bjerkandera adusta and Lentinus brumalis when paired separately with Trametes versicolor in both agar and sugar maple (Acer saccharum) $[47,59]$. The ascomycete Xylaria polymorpha has been used extensively to form zone lines without a fungal antagonist $[55,60]$. For commercial zone line production with X. polymorpha, Robinson and Laks [55] had greater success for aspen (Populus tremuloides), sugar maple (Acer saccharum), birch (Betula spp.), and basswood (Tilia americana). The latter are all diffuse-porous hardwood species. The chemical and anatomical characteristics that favour zone line formation without a fungal antagonist have not been identified.

Although the techniques described can produce spalted wood more quickly than through natural colonisation, those methods are unreliable and too slow to meet industry requirements for speed and volume of production (Fig. 5). Significant loss in mechanical strength is a particular concern for traditional approaches to spalting. Long incubation periods, especially with white rot fungi, gives the craftsman little control over the spalting process and the loss of wood mechanical strength and stability. Improvements in methods will likely come from laboratory screening and testing of small wood samples with various fungi, alone and in combination. Then, techniques can be successfully adjusted for larger samples with the goal to spalt table-top sized wood stock.

An alternative approach is to artificially induce zone lines formation with a single fungus exposed to highly localized chemical stress. In tests with $X$. polymorpha, the fungus was grown on wood in culture. Copper sulphate (a fungicide) was locally applied to the infected wood to effectively 'draw' zone lines on the wood surface [56]. Although effective and reliable in two spatial dimensions, copper sulphate treatment does not result in the desirable highly defined 3-dimensional display that results from direct fungal competition (Fig. $4 \mathrm{~A}-\mathrm{C}$ ).

\section{Standardising the spalting method for commercial-scale applications}

\subsection{Zone lines, wood mechanical properties, $\mathrm{pH}$ and wood moisture content}

Wood decay-fungi naturally degrade and depolymerise wood constituents with associated reductions of tensile strength, elasticity and stiffness $[80,86]$. For successful wood colonisation, most wood decayfungi generally require a wood moisture content above bound water capacity (approx. 30\% moisture content on a dry-weight basis, [62]) as water must be freely available for wood decay to occur. However, as these fungi are aerobic, mycelial growth and wood decay ceases as moisture increases towards the wood saturation. The following chapter describes bound water capacity (formerly fibre saturation point) in more detail with respect to soft rot decay fungi.

\subsection{Decay fungi and mechanical properties}

The ideal fungal species to produce zone lines on a commercial scale would result in the desired spalting with no marked alteration of mechanical properties. Mechanical properties of wood used for load bearing applications must meet industry standards (e.g. BS EN 1534 [9]). For spalted wood in the high-end furniture industry, mechanical wood values, which differ between wood species, should not be reduced by more than $10 \%$ for stiffness measurements or below $25 \%$ for Brinell surface hardness measurements [80].

Fungi used for spalting wood differ widely in their impact on the wood mechanical properties. White rot fungi degrade lignin, cellulose and hemicellulose at usually equal rates, secreting specialised enzymes that degrade all constituents of a lignified cell wall $[35,51,63]$. Decay

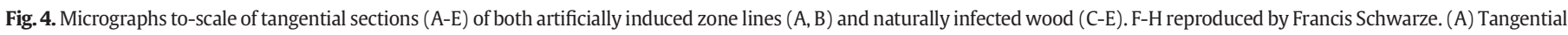

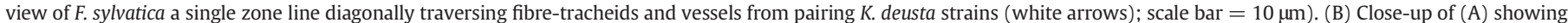

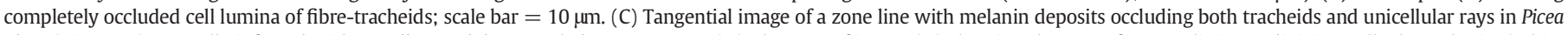

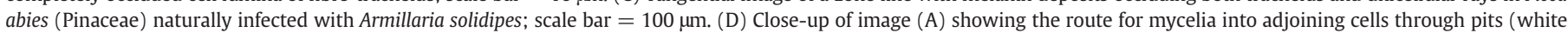

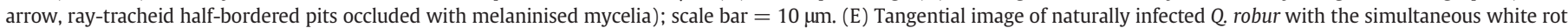

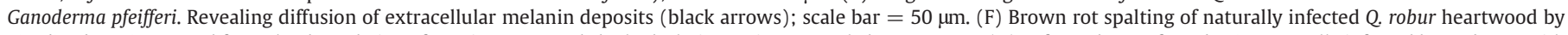

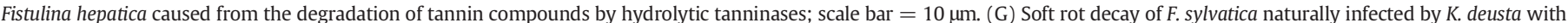

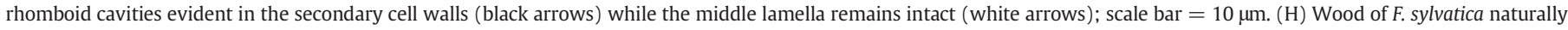

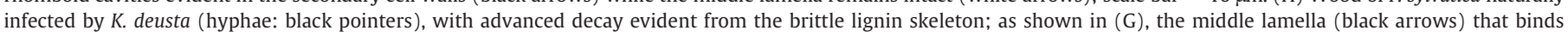
surrounding cells remains undecayed; scale bar $=20 \mu \mathrm{m}$. Fr, fibre; $\mathrm{Tr}$, tracheid, V, vessel; RP, ray parenchyma. 


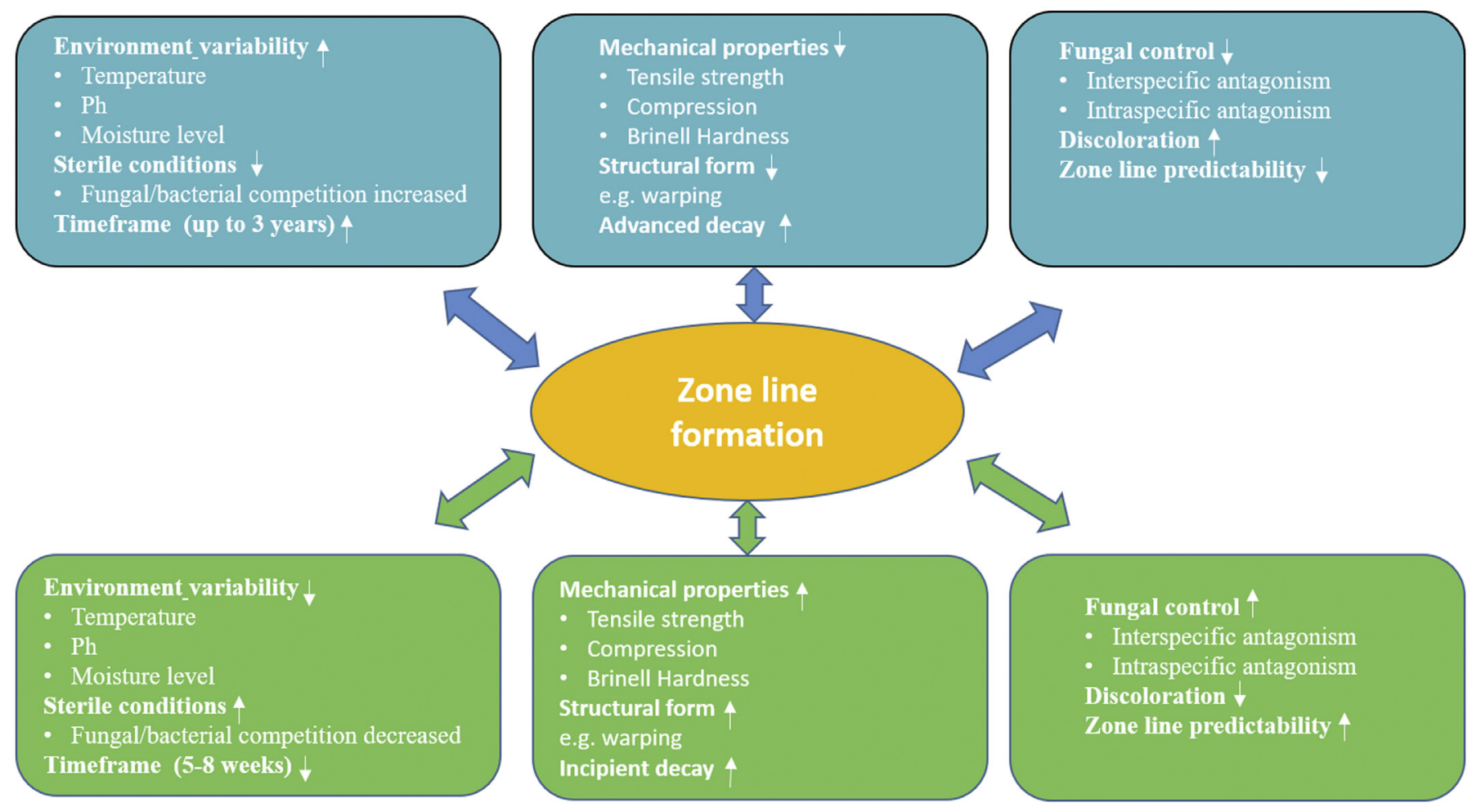

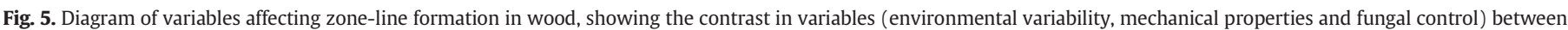

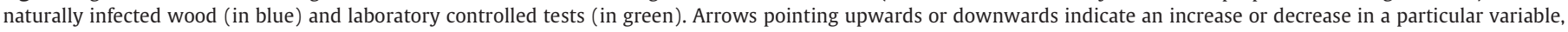
ultimately resulting in faster or slower zone-line formation.

associated with simultaneous white rot often results in a rapid loss of wood mechanical strength, the level of which varies depending on the fungus, the tree species and the wood conditions at time of infection. For instance, Bjerkandera adusta and Trametes versicolor can cause extensive decay followed by a rapid loss of mechanical stiffness and strength through degradation of the cell walls of all cell types including vessels, fibres and parenchyma [3]. Considering the extent of the decay and the speed at which it occurs, a short incubation period to induce zone lines is essential. Robinson et al. [59] showed that wood blocks of Acer saccharum (sugar maple) treated with L. brumalis and T. versicolor incubated for 10 weeks produced spalting without a significant loss of wood mechanical strength, which is an acceptable timeframe for large commercial upscaling.

\subsection{Soft rot fungi and mechanical properties}

Soft rot fungi (e.g. Daldinia concentrica, Xylaria polymorpha and $K$. deusta) preferentially form cavities in the $S_{2}$ secondary wall layer of wood cells, resulting in a slow loss of mechanical strength. All wood components except the compound middle lamella are subject to softrot decay (Schwarze et al., 2007). The persistence of lignin-rich regions of the wood matrix in trees decayed by $K$. deusta is not only due to their initially high high lignin content per se, but also to their high percentage of guaiacyl lignin. Members of the Xylariaceae have relatively poor lignolytic ability, mainly confined to the decomposition of syringyl lignin (Nilsson et al. [44]). There are also key differences in the life cycles of the two zone-line producing soft rots, $K$. deusta and X. polymorpha. The former is a facultative-parasite (saprotroph-necrotroph spectrum) penetrating functional sapwood ([46]; Deflorio et al. [17]), while the latter is a saprotroph surviving only on dead tissue. In functional sapwood, $K$. deusta can only slowly pass or breach reaction zones laid down by the host (Morris et al. [9,41]); pits become encrusted with polyphenols, initially blocking hyphal entrance points for the fungus (Fig. 2A in [42]). However, due to the absence of living parenchyma cells (responsible for reaction zone development) in processed timber, members of the Xylariaceae and in particular $K$. deusta, can form zone lines without obstruction from reaction zones during the inoculation process, a key advantage when using these fungal species to spalt wood.

\subsection{Kretzschmaria deusta and zone-line formation}

In preliminary trials at the bio-engineered wood laboratory, Empa, Switzerland, we found $K$. deusta to be exceptional as a spalting fungus owing to the retention of wood mechanical strength and form, even at advanced stages of decay [64]. K. deusta preferentially degrades fibres and the $\mathrm{S}_{2}$ layer of the secondary wall (Figs. $3 \mathrm{~A}-\mathrm{H}, \mathrm{M}, 6$ ), which has a high concentration of syringyl units, whereas cell types (vessels, tracheids, fibres) and cell wall layers (compound middle lamella) that are rich in guaiacyl units persist even at advanced stages of decay (Fig. 4G, H; [63,64]). K. deusta also performs better in artificial culture media, demonstrating much faster growth rates than X. polymorpha, likely enabling the former to spalt wood at a faster rate. In naturally infected trees, $K$. deusta causes extensive decay in large volumes of wood by switching from a soft rot to a white rot, leaving a pattern of very fine zone lines [81-84].

Also, for survival in dry wood, xylariaceous species like $K$. deusta are exceptional; their hyphae grow in the cell wall thus accessing bound water unavailable to most decay-fungi (in engineering, classified as moisture contents $<30 \%$ ). However, it must be made clear that moisture content $\%$ at the interface between cell wall saturation (bound water capacity) and capillary water in cell lumina (a prerequisite for decay propagation) is arbitrary and not scientifically accurate. Bound water capacity is more accurately defined as a gradual transition (i.e. phase boundary) rather than a fixed moisture content, as shown by low field nuclear magnetic resonance studies $[19,85]$. Traditionally, wood is kept at a minimum of $30 \%$ moisture content for successful inoculation as this is a preference for most decay fungi. Some zone line forming white rot decay fungi, such as Inonotus hispidus and Polyporus 

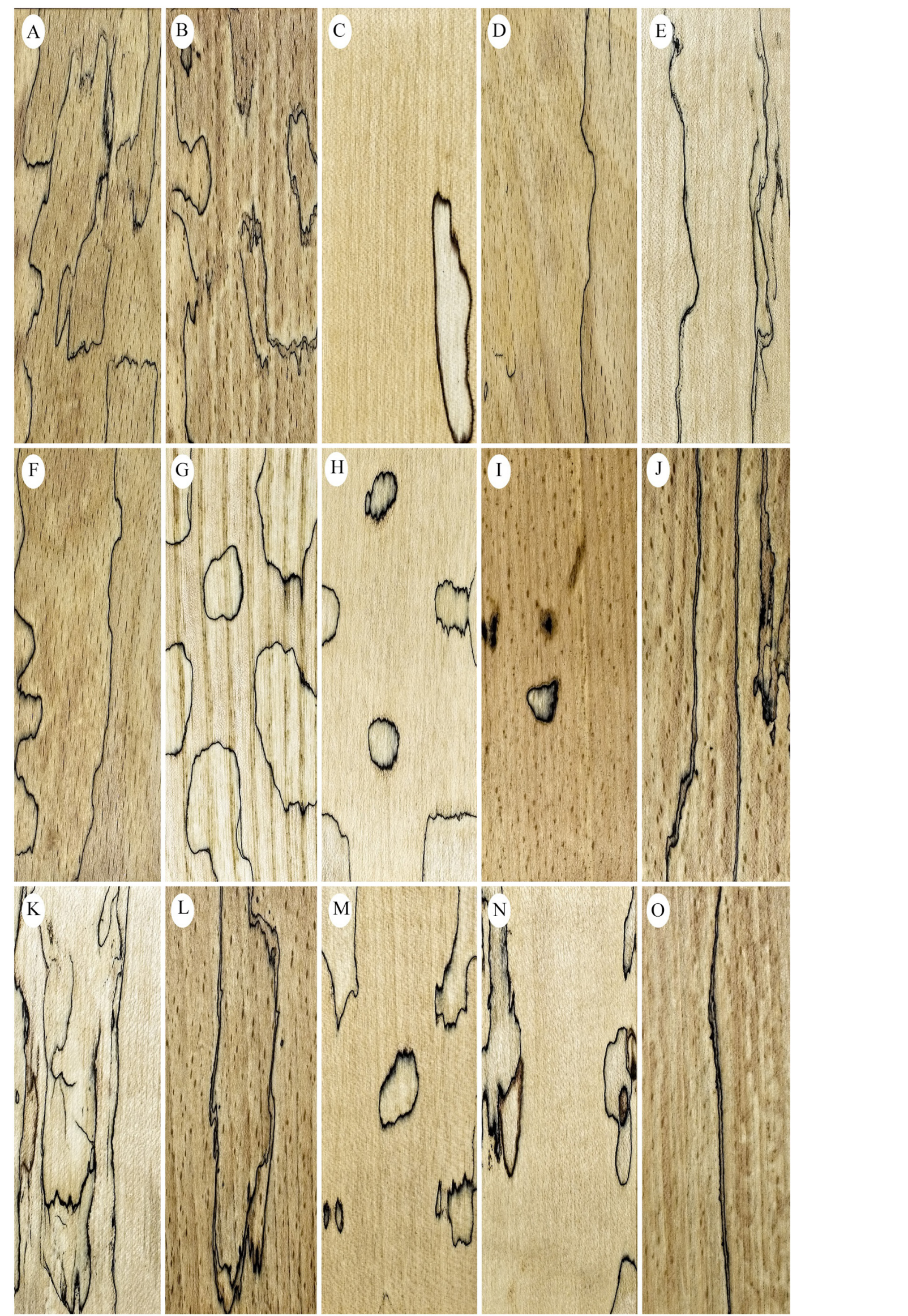
squamosus produce maximum pigmentation at wood moisture contents from 35 to $55 \%$, a range that depends on the fungus and the wood species [75]. However, if the wood moisture content is too high, oxygen availability, which is essential for the decay process, is reduced [5]. A key objective in producing zone lines in wood for furniture and paneling is to develop a process that allows the treatment of wood of a low moisture content (15-25\%) below bound water capacity. Such a method might be deemed favourable as the low wood moisture content lowers the risk of contamination, requires less energy for wood drying after treatment and provides wood with higher dimensional stability free from defects and deformations. Zone line induction at a lower moisture content would greatly reduce financial and environment costs when applied on a commercial scale.

\subsection{Incipient versus advanced decay and mechanical properties}

A critical point is that zone lines appear to be associated with incipient decay, meaning they occur during the early stages of decay when mechanical properties have not yet been altered to a significant degree $[29,68]$. Evidence of the early development of zone lines is also provided by Lopez-Real [37] stating that pigmentation, which follows hyphal swelling and hyphal aggregation, occurs in as few as five-days after inoculation for A. mellea and seven-days for Stereum hirsutum. Knowledge of the latter is of high importance during the application process, as determining the length of time required before stopping the spalting process is critical to provide zone-lined wood products that maintain strong mechanical properties. Determining the length of time for zone-line production also prevents the need to brace the wood, a common procedure in spalting when wood is left to decay for too long [16]. The timing of zone-line development will have to be considered during the upscaling process, as large pieces of wood will take longer to spalt. However, workers have not, to our knowledge, investigated whether or not fungi at an advanced decay stage produce zone lines.

\subsection{Effects of $\mathrm{pH}$ and temperature on zone-line formation and decay-fungi}

The $\mathrm{pH}$ of the wood substrate can vary within the tree along and across the stem, influencing the enzymatic activity of wood-degrading fungi and affecting decay rates $[46,62]$. While basidiomycetes prefer a slightly acidic environment, ascomycetes can tolerate a more alkaline habitat [30]. All these aspects of $\mathrm{pH}$ variation are reflected in fungal diversity and distribution of species succession in wood, where a knowledge of this is critically important to enable the operator to maximise spalting potential. The ability to manipulate fungal reactions through moisture content and $\mathrm{pH}$ changes in wood may offer a chance to enhance the pigmentation intensity and patterns currently available with spalted woods. However, as a number of decay fungi (e.g. Armillaria spp., Trametes spp.) have the ability to adjust their own $\mathrm{pH}$ and moisture content to favour their growth and nutrient assimilation, this makes these parameters difficult to control when producing zone lines $[14,28,38,39,70]$.
Along with $\mathrm{pH}$ and wood moisture content, species of wood decayfungi vary in temperature optima [26], which should be considered during the incubation process. Water activity tests (aw, $0-1$; the relative vapour pressure of a substrate) enable us to discover which species work best at a given temperature or even strains within a species where small temperature differences can help determine the success of zone-line formation. For instance, Fomes fomentarius (Fig. 2) has an optimum temperature from 27 to $30{ }^{\circ} \mathrm{C}$, Armillaria mellea prefers it slightly lower at $25-26{ }^{\circ} \mathrm{C}$ while Trametes versicolor has a broader optimum range of $24-33^{\circ} \mathrm{C}$ [62]. As zone lines are produced by the fungus under the duress of stress, artificially inducing stress by manipulating temperature and moisture might result in higher melanin production but at the expense of growth; this is an area of research that requires further attention.

\subsection{Current research on zone line formation}

From our trials at Empa, successful zone line formation in common beech (Fagus sylvatica), ash (Fraxinus excelsior) and maple wood (Acer pseudoplatanus) treated with $K$. deusta and Trametes pubescens occurred at $22{ }^{\circ} \mathrm{C}, 70 \%$ relative humidity and in wood of a moisture content between 15 and 25\%. Moreover, wood was never in direct contact with water, which ensured that wood moisture content remained low enough for $K$. deusta infection while maintaining plentiful oxygen supply for wood decay. The time required to produce 3-dimensional zone lines from paired antagonists (or more) both between fungal species and between strains of $K$. deusta ranged from 5 to 8 weeks depending on the size of the wood piece being tested (Fig. 6). Of interest, we found that the degree and competition and intensity of zone line formation varied greatly between fungal species and also between strains. Consequently, successful fungal pairing requires time and advanced screening beginning with antagonism tests in culture media before applications to wood.

\subsection{Future marketing potential of spalted wood}

The future potential of spalted wood is moving beyond wood turnery (unique fruit bowls, cups, etc), where the concept is now being adopted by furnishers of high design $[45,67]$. The furnisher can also tailor the product to the taste of the customer through control of patterns created by the fungi and by giving the products a unique identification number or GPS location from where the tree was felled, marketing that emphasises place and story. There is a growing shift towards wood in construction in general, which is linked to global climate change and sustainability. For example, wooden skyscrapers are being constructed around the world and could replace steel and concrete in the future as a more viable alternative ([72]; Ramage and Scherman [50]; [33]). To make office spaces distinct from each other within wood-framed skyscrapers, spalted partitions dividing office space could add appeal to the work space along with spalted interior wall cladding for inspiration, further opening new market potential.

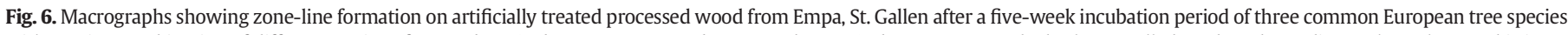

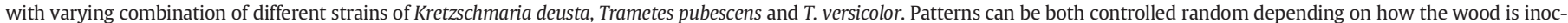

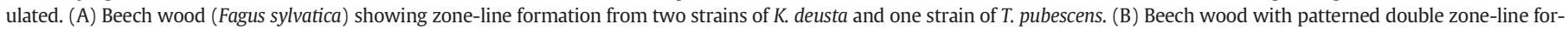

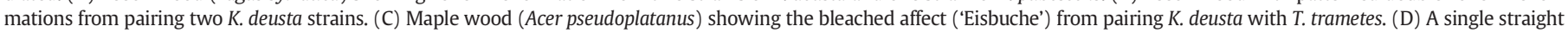

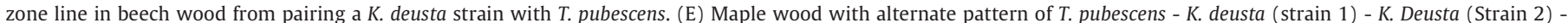

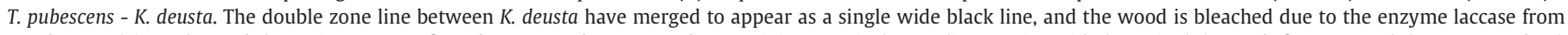

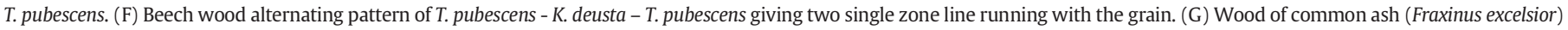

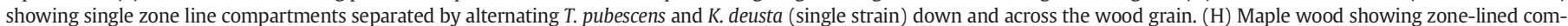

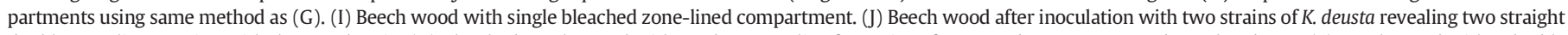

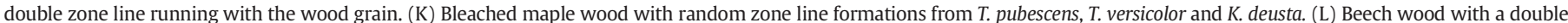

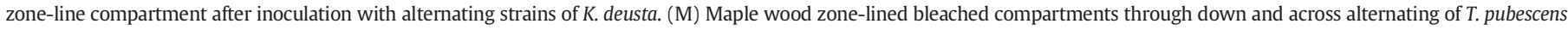

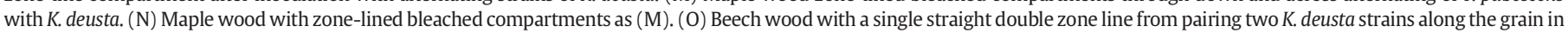
the centre of wood sample. 


\section{Discussion and future outlook}

Inducing spalting involves applying the scientific method to meet artistic ends with the aim of providing decorative wood products to niche markets. A successful approach to spalting wood on a large commercial scale should involve careful collaboration between wood scientists and industrial partners. The challenge is to develop a reliable and welldefined method to produce spalted wood of consistent high quality in a suitable time-frame while maintaining mechanical properties. Controlling the outcome, e.g. making zone lines that are curved, circular, rectangular, in zig-zag patterns, straight lines or double zone lines, etc., gives choice to the customer rather than leaving the process to random chance (Fig. 6). We should be able to guarantee the customer a minimalist design with few zone lines or a baroque pattern with many zone lines, accounting for the great variation in people's artistic senses. Also, retaining mechanical properties (i.e. stiffness and hardness) to meet industry regulations we need to assess a range of woods using different fungi to understand fungal growth under different temperature and $\mathrm{pH}$ regimes between and within species.

An important approach to optimise and homogenise the spalting method is to screen and select competitive strains of a single fungal species alongside developing a carrier system to easily and reliably apply fungi to wood. In a climate chamber, the operator can control the parameters such as temperature and humidity. Using glass windows, it is easier to investigate precisely when interaction zone lines occur with the knowledge that they form during incipient decay just prior to advanced wood decay. The latter observational studies can significantly reduce the timeframe from 6 months down to between 5 and 8 weeks, depending on the fungi and wood used. Soft rot fungi such as $K$. deusta may have advantages of being able to inoculate wood of low moisture contents thereby reducing opportunity for contamination while maintaining wood stability. However, white rot fungi (e.g. Trametes spp.) should not be overlooked in furniture applications, as they provide the bleaching effect that complements the zone line, known as "Eisbuche" in the German spalting industry (Fig. 6C). As an example, Trametes spp. can be paired with $K$. deusta to maximise the outcome with benefits from both fungi.

Finally, to help off-set carbon emissions in light of global warming, selecting the right tree species is critical. For instance, the wood of common ash, sycamore maple and European beech is relatively bright and unappealing compared to other more expensive woods. Specially selected wood decay-fungi can make the latter woods more attractive through fungal modification, giving the prized wood an aesthetic quality while sequestering carbon long-term. When properly dried, wood species normally burnt for energy production become valuable pieces of energy-preserving wood forms.

Spalted wood can yield a high price in niche speciality wood markets partly owing to its novelty and rarity. The high price reflects the time required to induce splalting when the wood is buried (6 months to three years to form zone lines). Also, with regards to spalted wood encountered by chance on the forest floor, the value of the wood can be high but lacks the mechanical strength and stability required for furniture, failing to meet industry standards (e.g. BS EN 1534 [9]). However, spalting induced through antagonism under controlled conditions of temperature, moisture, $\mathrm{pH}$ and relative humidity (e.g. in a climate chamber) will help to meet the high demand for these aesthetic wood products (Fig. 5). As an example of market value for spalted wood, the cost of logs of beech wood ( $F$. sylvatica) normally burnt for energy production in Switzerland amounts to approximately CHF $100-200 / \mathrm{m} 3$, but a quality sample of "spalted beech wood" would sell for an estimated CHF $2000-3000 / \mathrm{m} 3$. The economic potential of spalted wood supports the ambition to produce spalted wood under controlled laboratory conditions before successful upscaling and transfer to industry.

\section{Declaration of Competing Interest}

The authors declare that they have no known competing financial interests or personal relationships that could have appeared to influence the work reported in this paper.

\section{Acknowledgements}

The authors are grateful for the financial support by the KTI/ InnoSuisse Project No. 26083.1. Authors are in the order of contribution made. We thank Koster AG Holzwelten, Arnegg, Switzerland for assisting in the preparation of wood samples and for their technical support. We sincerely thank Kenneth Dudzik (USDA FS) for providing images Fig. 2H, I, J.

\section{Author contributions}

Hugh Morris and Francis W.M.R. Schwarze: Conceptualization, Hugh Morris: Writing - Original draft preparation: Hugh Morris, Kevin T. Smith, Francis W.M.R. Schwarze, Seri C. Robinson, Maximilian Göttelmann, Siegfried Fink: Writing - Reviewing and Editing. Hugh Morris, Kevin T. Smith, Francis W.M.R. Schwarze, Seri C. Robinson, Maximilian Göttelmann, Siegfried Fink: Visualization.

\section{Appendix A. Supplementary data}

Supplementary data to this article can be found online at https://doi. org/10.1016/j.matdes.2021.109480.

\section{References}

[1] T.J.H. Adams, N.K. Todd, A.D.M. Rayner, Antagonism between dikaryons of Piptoporus betulinus, Trans. Br. Mycol. Soc. 76 (1981) 510-513, https://doi.org/10. 1016/S0007-1536(81)80085-X.

[2] F.V.W. Appels, S. Camere, M. Montalti, E. Karana, K.M.B. Jansen, J. Dijksterhuis, P. Krijgsheld, H.A.B. Wösten, Fabrication factors influencing mechanical, moisture- and water-related properties of mycelium-based composites, Mater. Des. 161 (2019) 64-71, https://doi.org/10.1016/j.matdes.2018.11.027.

[3] E. Bari, N. Nazarnezhad, S.M. Kazemi, M.A.T. Ghanbary, B. Mohebby, O. Schmidt, C.A Clausen, Comparison between degradation capabilities of the white rot fungi Pleurotus ostreatus and Trametes versicolor in beech wood, Int. Biodeterior. Biodegradation 104 (2015) 231-237, https://doi.org/10.1016/j.ibiod.2015.03.033.

[4] A.A. Bell, M.H. Wheeler, Biosynthesis and function of fungal melanins, Annu. Rev. Phytopathol. 24 (1986) 441-451, https://doi.org/10.1146/annurev.py.24.090186. 002211.

[5] L. Boddy, Effect of temperature and water potential on growth rate ofwood-rotting basidiomycetes, Trans. Br. Mycol. Soc. 80 (1983) 141-149, https://doi.org/10.1016/ S0007-1536(83)80175-2.

[6] L. Boddy, Interspecific combative interactions between wood-decaying basidiomycetes, FEMS Microbiol. Ecol. 31 (2000) 185-194, https://doi.org/10.1111/j.15746941.2000.tb00683.x.

[7] L. Boddy, J. Hiscox, Fungal ecology: principles and mechanisms of colonization and competition by saprotrophic fungi, Microbiol. Spectr. 4 (2017) 6 , FUNK-009 https://www.jstor.org/stable/20113263.

[8] L. Boddy, E.M. Owens, I.H. Chapela, Small scale variation in decay rate within logs one year after felling: effect of fungal community structure and moisture content, FEMS Microbiol. Ecol. 62 (1989) 173-184, https://doi.org/10.1111/j.1574-6968. 1989.tb03691.x.

[9] BS EN 1534, Wood flooring and parquet, Determination of Resistance to Indentation. Test Method, 2020.

[10] A.H. Campbell, Zone lines in plant tissues. I. the black lines formed by Xylaria polymorpha (Pers.) Grev. In hardwoods, An. Appl. Biol. 20 (1933) 123-145. https://doi.org/10.1111/j.1744-7348.1933.tb07431.x.

[11] A.H. Campbell, Zone lines in plant tissues. II. The black lines formed by Armillaria mellea, An. Appl. Biol. 21 (1934) 1-22, https://doi.org/10.1111/j.1744-7348.1934. tb06887.x.

[12] A.H. Campbell, R.G. Munson, Zone lines in plant tissues. III. The black lines formed by Polyporus squamosus (Htjds.), Fr. An. Appl. Biol. 23 (1936) 453-464, https://doi.org/ 10.1111/j.1744-7348.1936.tb06103.x.

[13] K.T.St.G. Cartwright, A re-investigation into the cause of "Brown Oak", Fistulina hepatica (Huds.), Fr. Trans. Br. Mycol. Soc. 21 (1937) 68-83, https://doi.org/10.1016/ S0007-1536(37)80006-6.

[14] I.H. Chapela, L. Boddy, Fungal colonization of attached beech branches II. Spatial and temporal organization of communities arising from latent invaders in bark and 
functional sapwood, under different moisture regimes, New Phytol. 110 (1988) 47-57, https://doi.org/10.1111/j.1469-8137.1988.tb00236.x.

[15] E. Dadachova, R.A. Bryan, X. Huang, T. Moadel, A.D. Schweitzer, P. Aisen, J.D. Nosanchuk, A. Casadevall, Ionizing radiation changes the electronic properties of melanin and enhances the growth of melanized fungi, PLoS One 2 (2007) e457, https://doi.org/10.1371/journal.pone.0000457.

[16] D.R. de Oliveira, C.C. Andersen, S. Vega Gutierrez, F.A. Kambe, S.C. Robinson, Method of stabilizing heavily spalted big leaf maple as a decorative coating veneer layer for engineered wood flooring, Coatings 9 (2019) 132, https://doi.org/10.3390/ coatings9020132.

[17] G. Deflorio, C. Johnson, S. Fink, F.W.M.R. Schwarze, Decay development in living sapwood of coniferous and deciduous trees inoculated with six wood decay fungi, For. Ecol. Manag. 255 (2008) 2373-2383, https://doi.org/10.1016/j.foreco.2007.12.040.

[18] D. Floudas, M. Binder, R. Riley, K. Barry, R.A. Blanchette, et al., The paleozoic origin of enzymatic lignin decomposition reconstructed from 31 fungal genomes, Science 2336 (2012) 1715-1719, https://doi.org/10.1126/science.1221748.

[19] M. Fredriksson, E.E. Thybring, On sorption hysteresis in wood: separating hysteresis in cell wall water and capillary water in the full moisture range, PLoS One 14 (2019), e0225111, https://doi.org/10.1371/journal.pone.0225111.

[20] S. Gantz, S. Steudler, H. Delenk, A. Wagenführ, T. Bley, Zone line formation on artificial media and in hardwoods by basidiomycetes for production of spalted wood, Holzforschung 71 (2017) 833-841, https://doi.org/10.1515/hf-2016-0222.

[21] H. Guo, D. Klose, Y. Hou, G. Jeschke, I. Burgert, Highly efficient UV protection of the biomaterial wood by A transparent TiO2/Ce Xerogel, ACS Appl. Mater. Interfaces 8 (2017) 39040-39047, https://doi.org/10.1021/acsami.7b12574.

[22] P. Groom, 'Brown oak' and its origin, Ann. Bot. 29 (1915) 393-408, https://doi.org/ 10.1093/oxfordjournals.aob.a089554.

[23] R. Hartig, Wichtige Krankheiten der Waldbäume: Beiträge zur Mykologie und Phytopathologie für Botaniker und Forstmänner, Springer-Berlin, 1874.

[24] J. Heilmann-Clausen, A gradient analysis of communities of macrofungi and slime moulds on decaying beech logs, Mycol. Res. 105 (2001) 575-596, https://doi.org/ $10.1017 /$ S0953756201003665.

[25] J. Hiscox, L. Boddy, Armed and dangerous - chemical warfare in wood decay communities, Fungal Biol. Rev. 31 (2017) 169-184, https://doi.org/10.1016/j.fbr.2017. 07.001 .

[26] J. Hiscox, G. Clarkson, M. Savoury, G. Powell, I. Savva, M. Lloyd, J. Shipcott, A. Choimes, X.A. Cumbriu, L. Boddy, Effects of pre-colonisation and temperature on interspecific fungal interactions in wood, Fungal Ecol. 21 (2016) 32-42, https://doi. org/10.1016/j.funeco.2016.01.011.

[27] J. Hiscox, J. O'Leary, L. Boddy, Fungus wars: basidiomycete battles in wood decay, Stud. Mycol. 89 (2018) 117-124, https://doi.org/10.1016/j.simyco.2018.02.003.

[28] J. Hiscox, M. Savoury, C.T. Müller, B.D. Lindahl, H.J. Rogers, L. Boddy, Priority effects during fungal community establishment in beech wood, ISME J. 9 (2015) 2246-2260, https://doi.org/10.1038/ismej.2015.38.

[29] E.E. Hubert, The diagnosis of decay in wood, J. Agric. Res. 29 (1924) 523-567.

[30] M. Humar, M. Petric, F. Pohleven, Changes of the $\mathrm{pH}$ value of impregnated wood during exposure to wood-rotting fungi, Holz Roh-Werkstoff 59 (2001) 288-293, https://doi.org/10.1007/s001070100207.

[31] P.M. Kirk, P. Cannon, D.W. Minter, J. Stalpers, Ainsworth \& Bisby's Dictionary of the Fungi, CABI Pub, New York, 2008.

[32] F.S. Krah, C. Bässler, C. Heibl, J. Soghigian, H. Schaefer, D.S. Hibbett, Evolutionary dynamics of host specialization in wood-decay fungi, BMC Evol. Biol. 18 (2018) 119, https://doi.org/10.1186/s12862-018-1229-7.

[33] D. Lazarevic, P. Kautto, R. Antikainen, Finland's wood-frame multi-storey construction innovation system: Analysing motors of creative destruction, Forest Policy Econ. 110 (2020), 101861, https://doi.org/10.1016/j.forpol.2019.01.006.

[34] C.T. Li, Phenoloxidase and peroxidase activities in zone lines of Phellinus weirii, Mycologia 73 (1981) 811-821, https://doi.org/10.1080/00275514.1981.12021412.

[35] W. Liese, The action of fungi and bacteria during wood deterioration, Rec. Ann. Conv. Br. Wood Pres. Assoc. 4 (1970) 1-4.

[36] M. Lindquist, Spalted wood. Rare jewels from death and decay, Fine Woodworking 7 (1977) 50-53.

[37] J.M. Lopez-Real, Formation of pseudosclerotia ('zone lines') in wood decayed by Armillaria mellea and Stereum hirsutum: I. morphological aspects, Trans. Br. Mycol. Soc. 62 (1975) 465-471, https://doi.org/10.1016/S0007-1536(75)80145-8.

[38] J.M. Lopez-Real, M.J. Swift, The formation of pseudosclerotia ('zone lines') in wood decayed by Armillaria mellea and Stereum hirsutum: II. Formation in relation to the moisture content of the wood, Trans. Br. Mycol. Soc. 64 (1975) 479-481, https:// doi.org/10.1016/S0007-1536(75)80146-X

[39] J.M. Lopez-Real, M.J. Swift, Formation of pseudosclerotia ('zone lines') in wood decayed by Armillaria mellea and Stereum hirsutum: III. Formation in relation to the gaseous atmosphere in wood, Trans. Br. Mycol. Soc. 66 (1977) 321-325, https://doi.org/10.1016/S0007-1536(77)80183-6.

[40] V. Meyer, E.Y. Basenko, J.P. Benz, et al., Growing a circular economy with fungal biotechnology: a white paper, Fungal Biol. Biotechnol. 7 (2020) 5, https://doi.org/10. 1186/s40694-020-00095-z.

[41] H. Morris, C. Brodersen, F.M.W.R. Schwarze, S. Jansen, The parenchyma of secondary xylem and its critical role in tree defense against fungal decay in relation to the CODIT model, Front. Plant Sci. 7 (2016) 1665, https://doi.org/10.3389/fpls.2016. 01665.

[42] H. Morris, A.M. Hietala, S. Jansen, J. Ribera, S. Rosner, K. Salmeia, F. Schwarze, Using the CODIT model to explain secondary metabolites of the xylem in defence systems of temperate trees to decay fungi, Ann. Bot. 125 (2020) 701-720, https://doi.org/10. 1093/aob/mcz138.

[43] E.E. Nelson, Survival of Poria weirii in wood buried in urea-amended forest soil, Phytopathology 65 (1975) 501-502, https://doi.org/10.1094/Phyto-65-501.
[44] T. Nilsson, G. Daniel, Interactions between soft-rot fungi and CCA preservatives in Betula verrucosa, J. Inst. Wood Sci. 11 (1989) 162-171.

[45] J. Parker, Opportunities in Forestry: Specialty Wood, Michigan State University, 2019 https://www.canr.msu.edu/news/opportunities-in-forestry-specialty-wood (Accessed 28 December 2020)

[46] R.B. Pearce, Reaction zone relics and the dynamics of fungal spread in the xylem of woody angiosperms, Physiol. Mol. Plant Pathol. 39 (1991) 41-55, https://doi.org/10. 1016/0885-5765(91)90030-L.

[47] L.W. Phillips, The Nature of Spalted Wood: Analysis of Zone Line Formation between Six White Rot Fungi, Thesis Master of Science, Brigham Young University, 1987

[48] L. Pittis, D. Rodrigues de Oliveira, S.M. Vega Gutierrez, S.C. Robinson, Alternative carrier solvents for pigments extracted from spalting fungi, Materials (Basel) 11 (2018) 897, https://doi.org/10.3390/ma11060897.

[49] S.R. Pombeiro-Sponchiado, G.S. Sousa, J.C. Andrade, H.F. Lisboa, R.C. Gonçalves, Production of melanin pigment by fungi and its biotechnological applications, in: $\mathrm{M}$. Blumenberg (Ed.), Melanin, InTech, London, UK 2017, pp. 47-74, https://doi.org/ $10.5772 / 67375$.

[50] M.H. Ramage, H. Burridge, M. Busse-Wicher, G. Fereday, T. Reynolds, D.U. Shah, G Wu, L. Yu, P. Fleming, D. Densley-Tingley, J. Allwood, P. Dupree, P.F. Linden, O. Scherman, The wood from the trees: the use of timber in construction, Renew. Sust. Energ. Rev. 68 (2017) 333-359, https://doi.org/10.1016/j.rser.2016.09.107.

[51] A.D.M. Rayner, L. Boddy, Fungal Decomposition of Wood: Its Biology and Ecology, John Wiley \& Sons, Chichester, 1988.

[52] A.D.M. Rayner, N.K. Todd, Intraspecific antagonism in natural populations of wooddecaying basidiomycetes, J. Gen. Microbiol. 103 (1977) 85-90, https://doi.org/10. 1099/00221287-103-1-85.

[53] J. Ribera, G. Panzarasa, A. Stobbe, A. Osypova, P. Rupper, D. Klose, F.W.M.R. Schwarze, Scalable biosynthesis of melanin by the basidiomycete Armillaria cepistipes, J. Agric. Food Chem. 67 (2019) 132-139, https://doi.org/10.1021/acs.jafc.8b05071.

[54] S.C. Robinson, Developing fungal pigments for "painting" vascular plants, Appl. Microbiol. Biotechnol. 93 (2012) 1389-1394, https://doi.org/10.1007/s00253-0113858-2.

[55] S.C. Robinson, P.E. Laks, Culture age and wood species affect zone line production of Xylaria polymorpha, Open Mycol. J. 4 (2010) 18-21, https://doi.org/10.2174/ 1874437001004010018.

[56] S.C. Robinson, P.E. Laks, D.L. Richter, Stimulating spalting in sugar maple using sublethal doses of copper, Eur. J. Wood Prod. 69 (2011) 527-532, https://doi.org/10. 1007/s00107-010-0479-x.

[57] S.C. Robinson, P.E. Laks, E.J. Turnquist, A method for digital color analysis of spalted wood using Scion image software, Materials 2 (2009) 62-75, https://doi.org/10. 3390/ma2010062

[58] S.C. Robinson, H. Michaelsen, J.C. Robinson, Spalted Wood: The History, Science, and Art of a Unique Material, Schiffer Publishing, Ltd., Atglen, PA, USA, 2016.

[59] S.C. Robinson, D.L. Richter, P.E. Laks, Colonization of sugar maple by spalting fungi, For. Prod. J. 57 (2007) 24-32.

[60] S.C. Robinson, D. Tudor, G. MacDonald, Y. Mansourian, P.A. Cooper, Repurposing mountain pine beetle blue wood for art through additional fungal colonization, Int. Biodeterior. Biodegradation 85 (2013) 372-374, https://doi.org/10.1016/j. ibiod.2013.08.021.

[61] S.C. Robinson, G. Weber, E. Hinsch, S.M. Vega Gutierrez, L. Pittis, S. Freitas, Utilizing extracted fungal pigments for wood spalting: A comparison of induced fungal pigmentation to fungal dyeing, J. Coat. 2014 (2014) 1-8, https://doi.org/10.1155/ 2014/759073.

[62] O. Schmidt, Wood and Tree Fungi: Biology, Damage, Protection, and Use, SpringerVerlag, Berlin, 2006.

[63] F.W.M.R. Schwarze, Wood decay under the microscope, Fungal Biol. Rev. 21 (2007) 133-170, https://doi.org/10.1016/j.fbr.2007.09.001.

[64] F.W.M.R. Schwarze, D. Lonsdale, C. Mattheck, Detectability of wood decay caused by Ustulina deusta in comparison with other tree decay fungi, Eur. J. Plant Pathol. 25 (1995) 327-341, https://doi.org/10.1111/j.1439-0329.1995.tb01348.x.

[65] F.W.M.R. Schwarze, H. Morris, Banishing the myths and dogmas surrounding the biotech Stradivarius, Plants People Planet 2 (2020) 237-243, https://doi.org/10. 1002/ppp3.10097.

[66] A.L. Shigo, Compartmentalization: a conceptual framework for understanding how trees grow and defend themselves, Annu. Rev. Phytopathol. 22 (1984) 189-214, https://doi.org/10.1146/annurev.py.22.090184.001201.

[67] A. Sims, The Improbable Wood Grain You're Going to be Seeing More, Architectural Digest, 2017 https://www.architecturaldigest.com/story/spalted-wood-trend (accessed 28 December 2020).

[68] K.T. Smith, Zone lines, in: O.C. Malloy, T.D. Murray (Eds.), Encyclopedia of Plant Pathology, John Wiley \& Sons, New York 2001, pp. 1217-1218.

[69] K.T. Smith, Whither compartmentalization of decay in trees? A commentary on: 'Using the CODIT model to explain secondary metabolites of xylem in defence systems of temperate trees against decay fungi', Ann. Bot. 125 (2020) 4-6, https://doi. org/10.1093/aob/mcaa035.

[70] Smith, K.T., Shortle, W.C., 1991. Decay fungi increase the moisture content of dried wood in: Rosmoore, H.W., (Eds.) Biodeterioration and Biodegradation. Elsevier, New York, pp. 138-146.

[71] M.H.T. Stappers, A.E. Clark, V. Aimanianda, S. Bidula, D.M. Reid, P. Asamaphan, S.E Hardison, I.M. Dambuza, I. Valsecchi, B. Kerscher, A. Plato, C.A. Wallace, R. Yuecel, B. Hebecker, M. da Glória Teixeira Sousa, C. Cunha, Y. Liu, T. Feizi, A.A. Brakhage, K.J. Kwon-Chung, N.A.R. Gow, M. Zanda, M. Piras, C. Zanato, M. Jaeger, M.G. Netea, F.L. van de Veerdonk, J.F. Lacerda, A. Campos, A. Carvalho, J.A. Willment, J.P. Latgé, G.D. Brown, Recognition of DHN-melanin by a C-type lectin receptor is required for immunity to Aspergillus, Nature 555 (2018) 382-386, https://doi.org/10.1038 nature25974. 
[72] J. Tollefson, The wooden skyscrapers that could help to cool the planet, Nature 545 (2017) 280-282, https://doi.org/10.1038/545280a.

[73] A.N. Tran-Ly, C. Reyes, W.M.R. Schwarze, J. Ribera, Microbial production of melanin and its various applications, World J. Microbiol. Biotechnol. 36 (2020) 170, https:// doi.org/10.1007/s11274-020-02941-z.

[74] A.N. Tran-Ly, J. Ribera, F.W.M.R. Schwarze, M. Brunelli, G. Fortunato, Fungal melaninbased electrospun membranes for heavy metal detoxification of water, SM\&T 23 (2020), e00146, https://doi.org/10.1016/j.susmat.2019.e00146.

[75] D. Tudor, S.C. Robinson, P.A. Cooper, The influence of moisture content variation on fungal pigment formation in spalted wood, AMB Express 2 (2012) 69, https://doi. org/10.1186/2191-0855-2-69.

[76] D. Tudor, S.C. Robinson, T.L. Krigstin, P.A. Cooper, Microscopic investigation on fungal pigment formation and its morphology in wood substrates, Open Mycol. J. 8 (2014) 174-186, https://doi.org/10.2174/1874437001408010174.

[77] A. Unger, A.P. Schniewind, W. Unger, Conservation of Wood Artifacts: A Handbook, Springer-Verlag, Berlin, 2001.

[78] R.C. Van Court, S.C. Robinson, Stimulating production of pigment-type secondary metabolites from soft rotting wood decay fungi ("spalting" fungi), Adv. Biochem. Eng. Biotechnol. 169 (2019) 109-124, https://doi.org/10.1007/10_2019_93.

[79] J.H. White, On the biology of Fomes applanatus (Pers.), Wallr. Trans. Roy. Canad. Inst. 12 (1920) 133-174.
[80] W.W. Wilcox, Review of literature on the effects of early stages of decay on wood strength, Wood Fiber Sci. 9 (1978) 252-257.

[81] W.H. Wilkins, Studies in the genus Ustulina with special reference to parasitism. II. A disease of the common lime (Tilia vulgaris Hayne) caused by Ustulina, Trans. $\mathrm{Br}$. Mycol. Soc. 20 (1936) 133-156, https://doi.org/10.1016/S0007-1536(36)80007-2.

[82] W.H. Wilkins, Studies in the genus Ustulina with special reference to parasitism. IV. Conidia - germination and infection, Trans. Br. Mycol. Soc. 23 (1939) 65-85, https:// doi.org/10.1016/S0007-1536(39)80016-X.

[83] W.H. Wilkins, Studies in the genus Ustulina with special reference to parasitism. V. A disease of elm (Ulmus campestris Sm.) caused by Ustulina, Trans. Br. Mycol. Soc. 23 (1939) 171-185, https://doi.org/10.1016/S0007-1536(39)80022-5.

[84] W.H. Wilkins, Studies in the genus Ustulina with special reference to parasitism. VI. A brief account of heart rot of beech (Fagus sylvatica L.) caused by Ustulina, Trans. Br. Mycol. Soc. 26 (1943) 169-170, https://doi.org/10.1016/S0007-1536(43)80024-3.

[85] S.L. Zelinka, S.V. Glass, J.E. Jakes, D.S. Stone, A solution thermodynamics definition of the fiber saturation point and the derivation of a wood-water phase (state) diagram, Wood Sci. Technol. 50 (2016) 443-462, https://doi.org/10.1007/s00226015-0788-7.

[86] R.A. Zabel, J.J. Morrell, Wood Microbiology: Decay and its Prevention, Academic Press, San Diego, CA, 1992. 